\title{
Morphological and Molecular Identification of Limnodrilus Claparede,1862 Species(clitellata: naiDIDAE) IN Tigris River, Baghdad/Iraq
}

\author{
E. O. Zaar \\ H. J. Jaweir ${ }^{*}$
}

Department of Biology, College of Science for Women, University of Baghdad, Baghdad, Iraq

*Corresponding author: enas.odaa.eo@gmail.com, haifabio47@gmail.com*

*ORCID ID: https://orcid.org/0000-0003-3958-1589*

Received 27/10/2019, Accepted 27/2/2020, Published Online First 11/1/2021, Published 1/6/2021

This work is licensed under a Creative Commons Attribution 4.0 International License.

\begin{abstract}
Sludge worm samples were collected from the Tigers River sediment during the period from November 2018 to June 2019 in Al Sarafiya District/ Baghdad- Iraq. Biometric morphological measurements focusing on the form of penis sheath and chaetal morphology were used for species identification, in addition to molecular analysis by amplification of conserved 18s rRNA encoding gene using ITS1 and ITS4 universal primers.According to the morphological measurement records, the results revealed the existence of Limnodrilus hoffmeisteri Claparede 1862, L. claparedeianus Ratzel, 1868 and L. cervix Brinkhurst 1963. Other two groups of specimens, with short penis sheath, were identified by molecular technology as $L$. hoffmeisteri complex, and L. claparedeianus.-cervix. Both species were considered as new record for Iraqi fauna, and had been registered in NCBI under the accession number LC497073 and LC497074 respectively
\end{abstract}

Key words: Limnodrilus cervix, L. claparedeianus, L. claparedeianus-cervix, LC 497073, L. hoffmeisteri, Limnodrilus hoffmeisteri complex, Iraq, LC497073, NCBI

\section{Introduction:}

The cosmopolitan genus Limnodrilus Claparède, 1862 (Clitellata: Oligochaeta: Naididae) live in the sediment/water interface and serve as live food for fish and aquatic organisms, and playing a key role in freshwater ecosystems. The worms enhance sediment resuspension which is an important process in oxygen and nutrient recycling (1). They are tolerant species to contamination and live in polluted environments (2), and use as indicators of organic pollution in aquatic environments and for assessment $(3,4)$. They are widely distributed in Iraqi surface water and well documented by many authors $(5,6,7,8,9)$.

Species of genus Limnodrilus are characterize by the absence of hair chaetae in the dorsal bundles. All chaetae with teeth of about equal length, and are similar on dorsal and ventral bundles, except for L. udekemianus, which is differentiate from other species by their chaetal morphology, in which, the anterior chaetae with the upper tooth thicker, and at least twice as long as lower, and bent almost at right angle. Posterior chaetae have equal teeth. Other species are identified according to the morphology of their male ducts, which is terminated inside the body with a tube- like chitinous penis sheath with variable length. The distal end of the tube is modified and showing great morphological differences $(10,11,12)$.

Phylogeny of Limnodrilus spp. was analyzed by (13) based on multi-locus database. The molecular analysis including the sequences of three mitochondrial genes (COI, 12S and 16S rDNA), and four nuclear markers (18S and 28S rRNA, Histone 3, and ITS). The authors suggested that Limnodrilus is monophyletic genus of Tubificinae prone to cryptic speciation, and divided into three groups, one of them contains morphospecies characterized by short cuticular penis sheaths and enlarged chaetae in anterior segments (L. udekemianus, $L . \quad$ silvani and $L$. grandisetosus). The second group is a small group of species with moderately long penis sheaths, (L. sulphurensis and $L$. profundicola). The third and largest group have long penis sheath which are exceptionally long in $L$. claparedeianus, $L$. maumeensis, in addition to the form, which is morphologically intermediate between $L$. claparedianus and L. cervix (12). 
Liu et al, (14) studied the species boundaries among $L$. hoffmeisteri, by investigating a large samples of specimens from the northern hemisphere using a combination of mitochondrial and nuclear markers, and they observed that the congruence among the independent estimates in the genealogical history provides evidence of ten actual species in L. hoffmeisteri species complex with great morphological variation in the length / width ratio and distal shape of the penis sheath, with a large overlap across species. They designated an individuals from the type locality in Switzerland as a neotype of L. hoffmeisteri sensu stricto, which are belongs to one of these ten species.

The aim of this study is to identify Limnodrilus spp. in Tigris River, Baghdad- Iraq, and to insure the identification of confused species by molecular analysis data.

\section{Materials and Methods:}

Tubificid worms were collected monthly, from the sediment of Tigris River at Al-Sarafiya District/ Baghdad-Iraq during the period from November 2018 to June2019. The sorted worms were fixed in $80 \%$ ethanol. The anterior third part of the worm was fixed on a clean microscopic slide; mount with lactophenol for examination of the penis sheath found in the segment XI. The length of penis sheath; its basal width; the length of the anterior chaetae; and the length of distal \& the proximal tooth of the chaetae were measured under compound microscope using ocular micrometer. Photos for each identification criterion were captured by microscope digital camera MC500. The specimen was identified to species level according to $(10,11,12)$

To ensure species identification, molecular technique was used by amplification of conserved 18s rRNA encoding gene using ITS1 and ITS4 universal primers. Genomic DNA was isolated from the worm's sample according to the protocol of ABIO pure Extraction (ABIO pure TM Total DNA) and the isolated DNA was subjected to PCR (OWL Electrophoresis System Thermo, USA). The PCR products were separated by $1 \%$ agarose gel electrophoresis and visualized using the Gel imaging system. A forward primer (5 TCCGTAGGTGAACCTGCGG-3`) and reverse primer (5'-TCCTCCGCTTATTGATATGC-3`) were used; primers set provided by Macrogen, Korea.

Reaction to PCR amplification was performed in a total volume of $25 \mu \mathrm{I}$ containing $3 n g / \mu 1$ DNA, $1 \mu \mathrm{M}$ of each primer, (1 X) Master Mix (Promega, USA), and then a Nuclease Free Water were added in to tube. The thermal cycling setup were performed as follows: Initial Denaturation at $95{ }^{\circ} \mathrm{C}$ for $5 \mathrm{~min}$, followed by 30 cycles of $95{ }^{\circ} \mathrm{C}$ for $30 \mathrm{~s}, 55^{\circ} \mathrm{C}$ for $30 \mathrm{~s}$ and $72^{\circ} \mathrm{C}$ for $30 \mathrm{~s}$ with final extension at $72^{\circ} \mathrm{C}$ for 7 min using a thermal Cycler (BioRad, USA).The PCR products were separated by $1 \%$ agarose gel electrophoresis and visualized using Gel imaging system and The Ethidium bromide stained bands in gel (Promega, USA). The $18 S$ rRNA gene sequencing was performed by Sanger sequencing using ABI3730XL, automated DNA sequences, by Macrogen Corporation-Korea. The results were received by email then analyzed using genius software.

A search for homology was carried out using the Basic Local Alignment Search Tool (BLAST) p rogram accessible online at the National Center for Biotechnology Information (NCBI) at (http:/www.n cbi.nih.gov) and the BioEdit program. Statistical analysis system (15) was used to analyze any significant differences between species by calculating the least significant differences values (LDS).

\section{Results and Discussion:}

A total of 3255 individual tubificid worms were collected, and 2734 individuals of them were mature and suitable for identification, which represented $84 \%$ of the total worms collected. Limnodrilus spp. represented $77 \%$ of the total identified worms, in addition to Branchiura sowerbyi (15\%); Potamothrix hammoniensis (3\%); Tubifex tubifex (3\%) and Aulodrilus pigueti (2\%). Three different groups of Limnodrilus were morphologically identified as Limnodrilus hoffmeisteri; L. claparedeianus, and L cervix with percentages of $53 \%$ and $28 \%$ and $4 \%$ respectively. Two groups of individuals with short penis sheath were identified by molecular technique as $L$. hoffmeisteri complex, with a percentage of $12 \%$ and L. claparedeianus -cervix with a percentage of $3 \%$ (Fig.1).

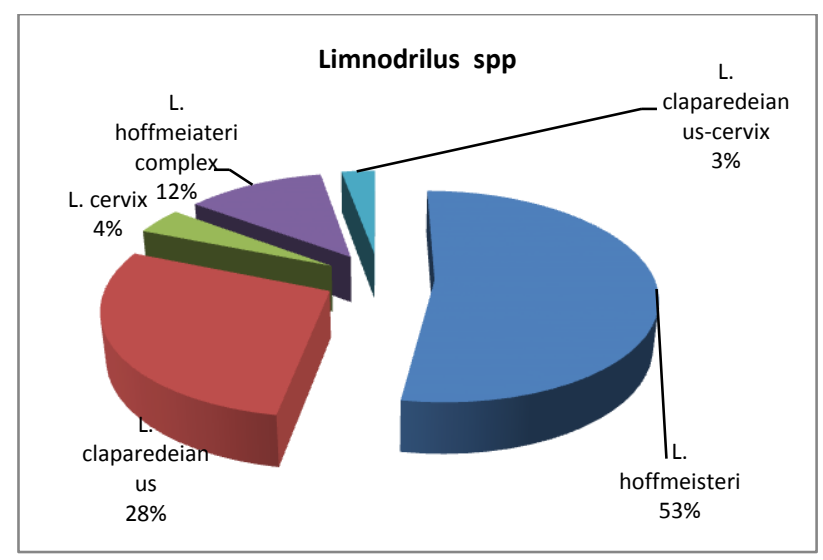


Figure 1. percentages of different Limnodrilus spp. from Tigris River /Baghdad-Iraq

Table 1 shows the biometric measurements of each species. L. hoffmeisteri had an average length of about $19 \mathrm{~mm}$, with 66 segments; The penis sheath was 4.2-18.0 times as long as width (average $10.96 \pm 3.17$ ) ( Plate 1A and B), and with two types of hood, one with symmetrical mushroom-like hood ( plate 1E), or plate topped hood (plate1D), and the other with typical asymmetrical hood (plate 1F). The latter form has longer penis sheath reach $570 \mu \mathrm{m}$. Some specimens which are not fully mature individuals have shorter, not fully developed penis sheaths. All forms have 5-9 chaetae in the anterior bundled, reduced to 2-5 in the posterior one, with about equal teeth (Plate 3 $\mathrm{A}$ and $\mathrm{B})$, the ratio of distal tooth / ventral teeth is $38 / 34$ (Table 2).

Table 1. Biometric measurements of different Limnodrilus spp collected from Tigris River/ BaghdadIraq

\begin{tabular}{|c|c|c|c|c|c|}
\hline \multirow{2}{*}{ species } & \multirow{2}{*}{$\begin{array}{l}\text { body length } \\
(\mathrm{mm} .)\end{array}$} & \multirow{2}{*}{ No. of segments } & \multicolumn{3}{|c|}{$\begin{array}{l}\text { penis sheath dimensions } \\
(\mu \mathrm{m})\end{array}$} \\
\hline & & & length (L) & width(W) & $\mathrm{L} / \mathrm{W}$ \\
\hline & $14-45$ & $24-140$ & $220-570$ & $20-70$ & 4.2-18 \\
\hline $\begin{array}{l}\text { Limnoarulus } \\
\text { hoffmeisteri }\end{array}$ & $\begin{array}{c}26.58 \pm 9.00 \\
a\end{array}$ & $\begin{array}{c}75.86 \pm 20.61 \\
\mathrm{Ab}\end{array}$ & $\begin{array}{c}432.71 \pm 76.46 \\
b\end{array}$ & $\begin{array}{c}41.71 \pm 9.61 \\
a\end{array}$ & $\begin{array}{c}10.96 \pm 3.17 \\
\mathrm{C}\end{array}$ \\
\hline & $7.50-33.25$ & 27-113 & 60-240 & $20-40$ & $3.0-6.8$ \\
\hline $\begin{array}{l}\text { L. hoffmeistert } \\
\text { complex }\end{array}$ & $\begin{array}{c}19.75 \pm 6.84 \\
\mathrm{a}\end{array}$ & $\begin{array}{c}66.38 \pm 21.11 \\
\mathrm{Ab}\end{array}$ & $\begin{array}{c}137.76 \pm 40,39 \\
\text { c }\end{array}$ & $\begin{array}{c}25.86 \pm 6.33 \\
b\end{array}$ & $\begin{array}{c}5.33 \pm 1.02 \\
\mathrm{C}\end{array}$ \\
\hline & $14.00-45.6$ & $50-120$ & $600-1250$ & $30-60$ & $15.0-29.0$ \\
\hline L. claparedeianus & $\begin{array}{c}\mathbf{3 0 . 0 3} \pm \mathbf{1 0 . 1 8} \\
\mathbf{a} \\
21-66\end{array}$ & $\begin{array}{c}\mathbf{7 6 . 6 2} \pm \mathbf{1 8 . 4 1} \\
\mathbf{A b} \\
60-120\end{array}$ & $\begin{array}{c}\mathbf{9 1 5 . 9 0} \pm \mathbf{1 5 4 . 0 2} \\
\mathbf{a} \\
920-1030\end{array}$ & $\begin{array}{c}\mathbf{4 3 . 2 6} \pm \mathbf{7 . 5 1} \\
\mathbf{a} \\
30-34\end{array}$ & $\begin{array}{c}\mathbf{2 1 . 3 8} \pm \mathbf{3 . 3 1} \\
\text { B } \\
30.0-30.6\end{array}$ \\
\hline L. cervix & $\begin{array}{c}36.15 \pm 20.26 \\
\text { a }\end{array}$ & $\begin{array}{c}81.00 \pm 26.72 \\
A\end{array}$ & $\begin{array}{c}950.00 \pm 57.16 \\
\text { a }\end{array}$ & $\begin{array}{c}31.00 \pm 2.00 \\
\text { b }\end{array}$ & $\begin{array}{c}30.60 \pm 0.71 \\
\mathrm{~A}\end{array}$ \\
\hline $\begin{array}{c}* \text { L. claparedeianus- } \\
\text { cervix }\end{array}$ & $\begin{array}{c}11 .-20 \\
\mathbf{1 7 . 4 6} \pm \mathbf{4 . 9 5} \\
\mathbf{a}\end{array}$ & $\begin{array}{c}45-84 \\
\mathbf{5 9 . 7 2} \pm \mathbf{1 3 . 4 2} \\
\text { A }\end{array}$ & $\begin{array}{c}100-330 \\
\mathbf{2 1 5 . 7 1} \pm \mathbf{7 5 . 4 7} \\
\text { c }\end{array}$ & $\begin{array}{c}20-40 \\
28.57 \pm 6.90 \\
\text { b }\end{array}$ & $\begin{array}{c}5.0-14.5 \\
\mathbf{7 . 7 0} \pm \mathbf{3 . 1 6} \\
\mathbf{C}\end{array}$ \\
\hline LDS values & $\begin{array}{r}23.73 \text { NS } \\
\text { means } h \\
\text { NS= No sig }\end{array}$ & $\begin{array}{l}\text { 18.06 S } \\
\text { *- Identified by mo } \\
\text { ve different letters } \\
\text { ificant differences; }\end{array}$ & $\begin{array}{l}\qquad 102.63 \mathrm{~S} \\
\text { lar techniques } \\
\text { th significant dif } \\
\text { with significant }\end{array}$ & $9.72 \mathrm{~S}$ & $7.39 \mathrm{~S}$ \\
\hline
\end{tabular}

Table 2. Measurements of anterior chaetal length; chaetal number, and the ratio of distal tooth / proximal tooth of different Limnodrilus spp collected from Tigris River/ Baghdad-Iraq

\begin{tabular}{|c|c|c|c|c|}
\hline \multirow[b]{2}{*}{ species } & \multirow{3}{*}{$\begin{array}{c}\text { number of chaetae in the } \\
\text { anterior bundles } \\
5-9\end{array}$} & \multicolumn{2}{|c|}{ length of anterior chaetae $(\mu \mathrm{m})$} & \multirow{2}{*}{$\begin{array}{l}\text { distal tooth/ } \\
\text { proximal tooth }\end{array}$} \\
\hline & & Dorsal & ventral & \\
\hline & & 80-147 & $85-132.5$ & \\
\hline $\begin{array}{l}\text { Limnodrilus } \\
\text { hoffmeisteri }\end{array}$ & $6.36 \pm 1.05$ & $112.21 \pm 12.40$ & $106.73 \pm 11.32$ & $38 / 34$ \\
\hline & $\begin{array}{c}\mathbf{a} \\
4-8\end{array}$ & $\begin{array}{c}\mathbf{a} \\
80-110\end{array}$ & $\begin{array}{c}\text { ab } \\
73-107.5\end{array}$ & \\
\hline $\begin{array}{l}{ }^{*} L . \text { hoffmeisteri } \\
\text { Complex }\end{array}$ & $\begin{array}{c}6.04 \pm 0.91 \\
a \\
5-8\end{array}$ & $\begin{array}{c}100.09 \pm 10.23 \\
\text { a } \\
85-1625\end{array}$ & $\begin{array}{c}94.43 \pm 11.19 \\
b \\
725-1475\end{array}$ & $32 / 29$ \\
\hline L. claparedeianus & $\begin{array}{c}6.39 \pm 0.84 \\
\text { a }\end{array}$ & $122.47 \pm 17.76$ & $\begin{array}{c}115.34 \pm 17.50 \\
\mathrm{a}\end{array}$ & $44-40$ \\
\hline & 6-7 & $105-130$ & $100-125$ & \\
\hline L. cervix 1 & $6.50 \pm 0.58$ & $\begin{array}{c}117.50 \pm 10.41 \\
\mathrm{a}\end{array}$ & $\begin{array}{c}110.00 \pm 11.37 \\
\text { ab }\end{array}$ & $41 / 36$ \\
\hline $\begin{array}{c}* \text { L. claparedeianus - } \\
\text { cervix }\end{array}$ & $\begin{array}{c}5-7 \\
6 \pm 0.82\end{array}$ & $\begin{array}{c}92.5-112.5 \\
\mathbf{1 0 5 . 0 0 \pm 6 . 7 7} \\
\text { a }\end{array}$ & $\begin{array}{c}80-107 \\
\mathbf{9 8 . 5 7 \pm 5 . 4 0} \\
\mathbf{a b}\end{array}$ & $39 / 35$ \\
\hline LDS values & $1.263 \mathrm{NS}$ & 19.024 NS & $17.662 \mathrm{~S}$ & \\
\hline & $\begin{array}{r}*_{\text {- Identifi }} \\
\text { means have differe } \\
\text { NS= No significant dif }\end{array}$ & $\begin{array}{l}\text { molecular techr } \\
\text { ers = with signif } \\
\text { es; } S=\text { with sig }\end{array}$ & $\begin{array}{l}\text { erence } \\
\text { lifferences }\end{array}$ & \\
\hline
\end{tabular}


Small specimens with short penis sheaths of length ranged from $60-240 \mu \mathrm{m}$, and the base width 20-30 $\mu \mathrm{m}$, with a ratio of $\mathrm{L} / \mathrm{W}$ was 3.0-6.8 (Table $1)$. The distal end is concave with plate-topped hood, sometime indistinguishable (Plate 1C). They have less, but similar chaetae with about equal teeth in each bundle (Plate 3C). The number of chaetae in the anterior bundle ranged from 4-7, with average length of 80-147 $\mu \mathrm{m}$, and the ratio of distal to proximal tooth length $29-32 \mu \mathrm{m}$. This form was identified by molecular techniques as Limnodrilus hoffmeisteri complex, and was certain by sequencebased phylogenetic analysis using $18 \mathrm{~S}$ ribosomal
RNA gene sequencing. The PCR product was subsequently sequenced to acquire DNA sequences and a 900 base pair product was acquired (Plate 4). This isolate was identified as L. hoffmeisteri complex, an $18 S$ rRNA encoding genomic sequence was resented to the NCBI and recorded with the accession number LC497073.

The amplicon was aligment at NCBI with B LAST, the $18 S r R N A$ isolated sequence worm showed $100 \%$ homology with the existing NCBI database sequence of Limnodrilus hoffmeisteri complex with accession number KY369413.1.

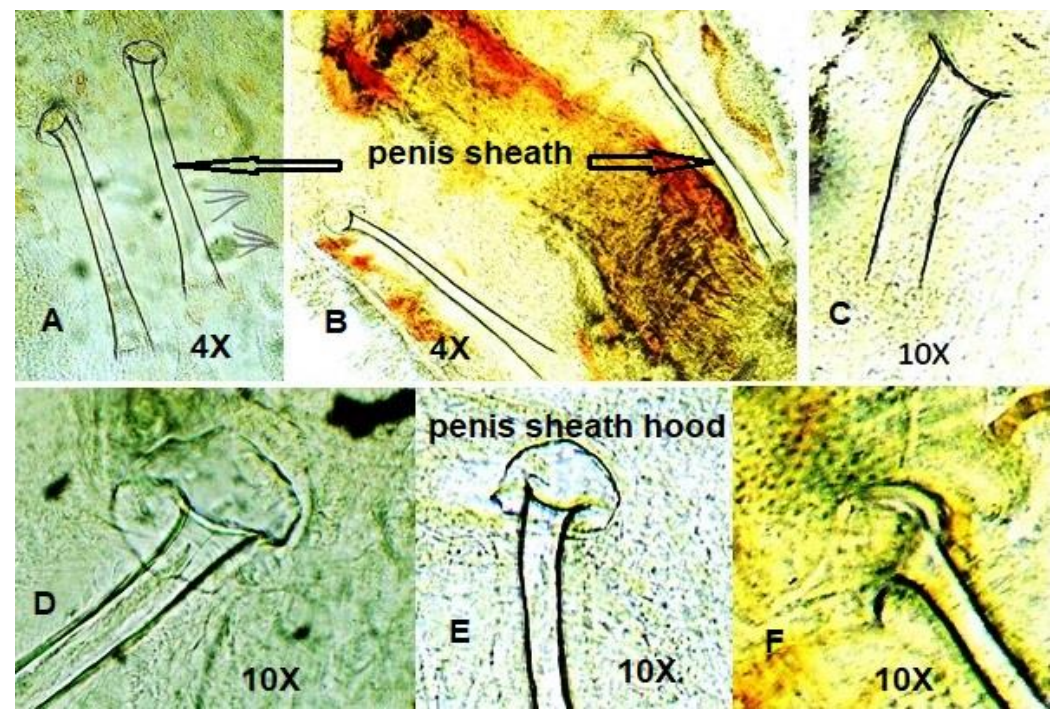

Plate 1. Types of penis sheath in L. hoffmeisteri complex, A\&B- long penis sheaths; C- short penis sheath with indistinguishable hood; D- plate-topped hood; E- Mushroom - like hood; F- typical asymmetrical hood

L. hoffmeisteri is a species widely distributed in Iraq and recorded by many authors as the most abundant among the tubificid worms in the Iraqi water systems $(5,8,9,16,17)$. The forms with short penis sheath were misidentified as $L$. profundicola $(9,18,19)$ due to its short penis sheath end with rounded hood. van Haaren \& Soors, (12) also indicated that less mature L. hoffmeisteri especially the form L. hoffmeisteri f. spiralis Eison 1879 can be confused with $L$. profundicola, but the authors referring to the widening of the alimentary canal and the presence of chloragogen tissue in $L$. profundicola, separate it from $L$. hoffmeisteri. They also indicated that length of penis sheath depends on the development stage of the individual, but the shape of the hood is constant in every stage, although, the hood may be missing in the immature specimens, and look like simple tube, as the shape which was noted in our specimens (Plate 1C).

L. claparedeianus have a penis sheath with 600-125 $\mu \mathrm{m}$ long (average $915 \mu \mathrm{m}$ ), and 30-50 $\mu \mathrm{m}$ width. The ratio of L/W ranged from15-29 (Table 1), with a narrow pear-like hood (Plate $2, \mathrm{~A} \& \mathrm{D})$, and there are 5-8 chaetae in the anterior bundles, with slightly longer distal tooth (Table 2 and plate 3 ), while in L. cervix the penis sheath is longer, with length ranged from 920-1030 $\mu \mathrm{m}$, and the width ranged from $30-34 \mu \mathrm{m}$, with the ratio $(\mathrm{L} / \mathrm{W})$ of 30.6. The wall of penis sheath in L. cervix with two layers, and the outer layer disappeared distally to leave a narrow neck. The distal head bears two triangle processes (Plate 2, B and C).

Few specimens with short penis sheath were identified by molecular techniques as $L$. claparedeianus - cervix, which has penis sheath with length ranged from $100-130 \mu \mathrm{m}$ and the width at the base $20-40 \mu \mathrm{m}$. The distal end has a triangularly rounded hood (Plate 2E). The result suggests that this form represents an immature specimen of the species, while the mature individuals were mixed with the other two species and unable to recognize. This species was considered as a new record in Iraq, and has been registered in NCBI under the accession number LC497074. 


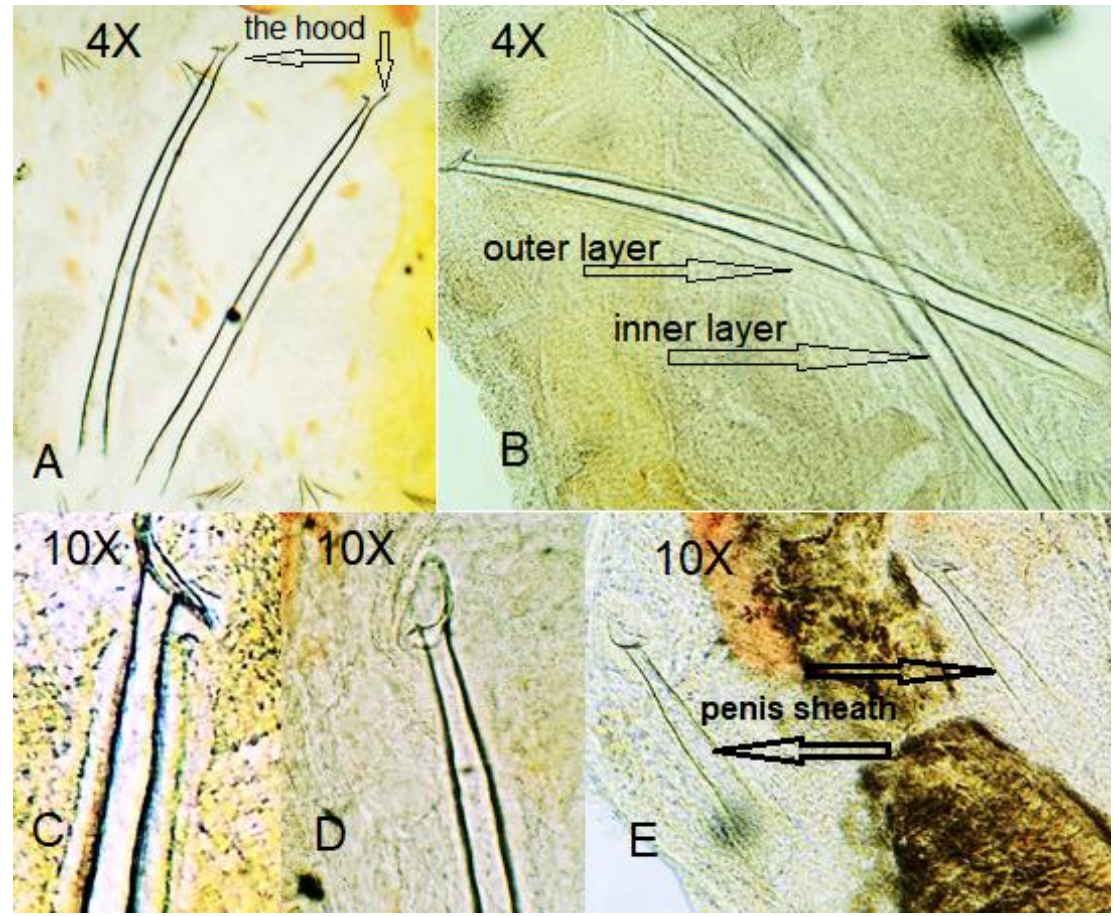

Plate 2. Types of penis sheaths in different Limnodrilus spp. A- L. claparedeianus; B- L. cervix; Canterior end of penis sheath in $L$. cervix ; D- anterior end of penis sheath in L. claparedeianus C; E- $L$. claparedeianus- cervix

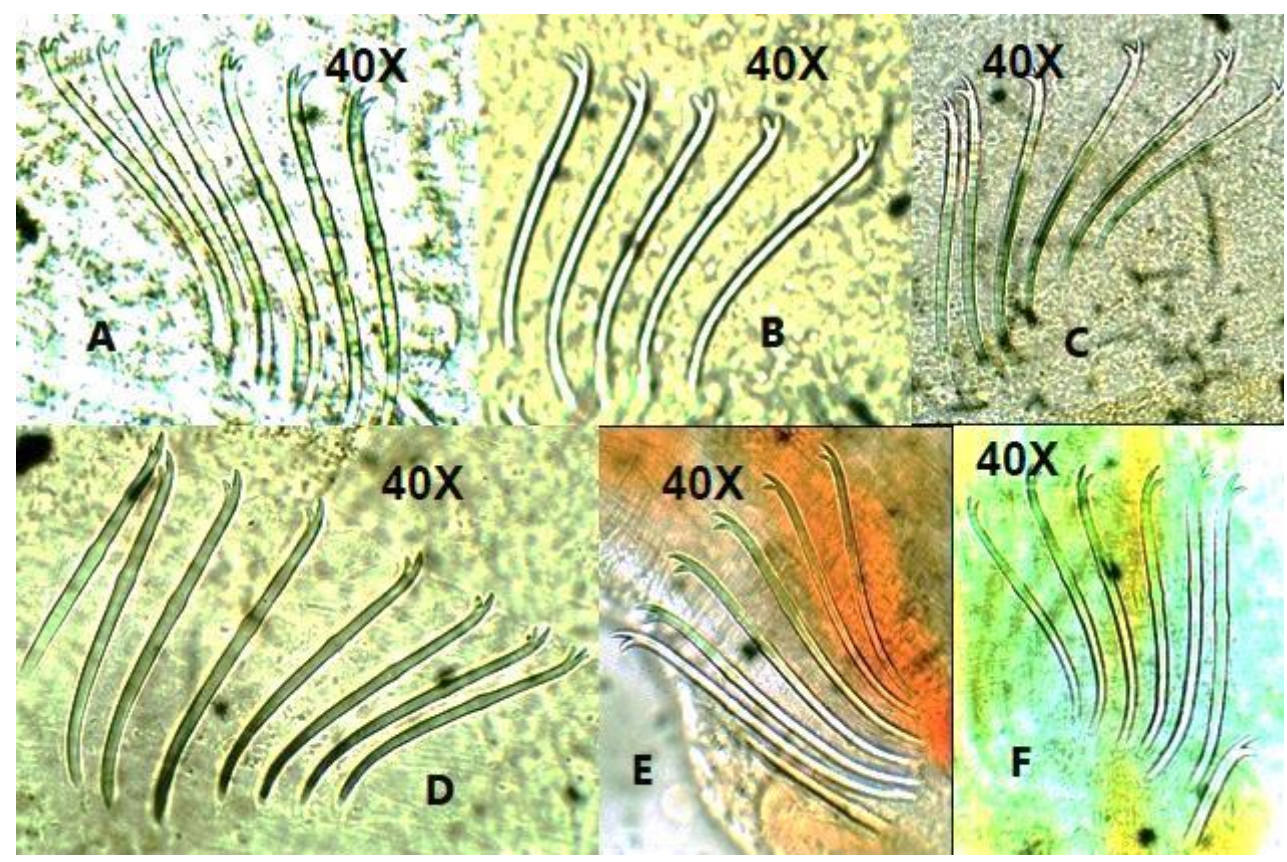

Plate 3. Types of anterior chaetae in different Limnodrilus species A, B \&C, L. hoffmeisteri; D, L. claparedianus; E, L. claparedeianus-cervix; F, L. cervix 


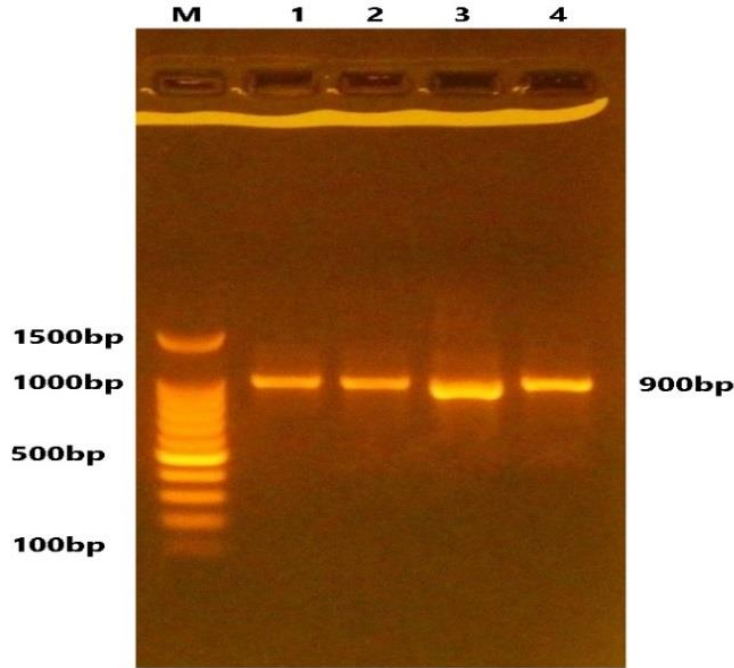

Plate 4. Amplified PCR product of band size 900 bp. Lane 1: the product was $1 \%$ agarose gel electrophoresis stained with Eth.Br. Lane1:100bp DNA marker at $1 \mathrm{v} / \mathrm{cm} 2$ for $1 \mathrm{~h}$, visualized using Gel imaging system

\section{Conclusion:}

Limnodrilus was the most frequent genus of tubificid worms in Tigris River, with L. hoffmeisteri as the dominant species, and its population consist of many forms, differ in their shape and size of penis sheathes. New form of $L$. hoffmeisteri with short penis sheath, and L. claparedeianus- cervix were recorded for the first time in Tigris River-Iraq. Therefore, Molecular analysis is important for the worm classification to promote the ambiguity of the classification of worm based on morphology features.

\section{Authors' declaration:}

- Conflicts of Interest: None.

- We hereby confirm that all the Figures and Tables in the manuscript are mine ours. Besides, the Figures and images, which are not mine ours, have been given the permission for republication attached with the manuscript.

- The author has signed an animal welfare statement.

- Ethical Clearance: The project was approved by the local ethical committee in University of Baghdad.

\section{References:}

1. Zhang L, Shang J, He W, You B, Fan C. The role of tubificid worms (Limnodrilus hoffmeisteri) in sediment resuspension: a microcosm study. Int.J. Limnol.. 2014; 50(3): 253-260.

2. Bassey A. Effect of Industrial Effluents on the Population Dynamics and Distribution of Benthic macro-invertebrates of New Calabar River, Southern Nigeria. IJBSR. 2019; 2(1):19-27.

3. Rodriguez P, Reynoldson TB. The pollution biology of aquatic oligochaetes. Springer Science,Business Media B.V. 2011; 265 pp.

4. Oztetik E, Cicek A, Arslan N. Early antioxidative defense responses in the aquatic worms (Limnodrilus sp.) in Porsuk Creek in Eskisehir (Turkey). Toxicol Ind Health. 2013; 29(6): 541-554.

5. Jaweir HJ, Al-Mukhtar EA, Sabtie HA. Aquatic Oligochaetes of Iraq's Southern Marshes. Baghdad Sci. J. 2012; 9(3): 472-480.

6. Jaweir HJ , Alwan AM. Sludge worm species (Oligochaeta: Naididae: Tubificinae) from different aquatic habitat in Baghdad/Iraq. Baghdad Sci. J. 2013; 10(2): 269-281.

7. Jaweir HJ. Checklist of aquatic oligochaetes species in Tigris -Euphrates River basin. Baghdad Sci. J. 2013; 11(3):1397-1404

8. Al-Abbad MY, Salman SD, Al-Garooni IH. Biodiversity and macroinvertebrates in the southern marshes with special reference to Oligochaeta. JBES. 2015; 7(1): 61- 71 .

9. Ibrahim SS. Biodiversity of Tubificidae in Rumaitha River-Iraq. JPSR. 2018; 10(8): 1947-1952.

10. Brinkhurst RO, Jamieson BG. Aquatic Oligochaeta of the World. Univ. of Toronto press, Canada. 1971; 860pp.

11. Timm T. A guide to the freshwater Oligochaeta and Polychaeta of Northern and Central Europe. Lauterbornia. 2009; 66: 1-23

12. Van Haaren T, Soors J. Aquatic Oligochaeta of the Netherlands and Belgium: Identification Key to the Oligochaetes. KNNV publishing, Zeist, The Netherlands, 2013; 302pp.

13. Liu Y, Fend SV. Martinsson S, Luo X, Ohtaka A, Erséus C. Multi-locus phylogenetic analysis of the genus Limnodrilus (Annelida: Clitellata: Naididae). Mol Phylogenet Evol. 2017; 112: 244-257.

14. Liu Y, Fend SV, Martinsson S, Erséus C . Extensive cryptic diversity in the cosmopolitan sludge worm Limnodrilus hoffmeisteri (Clitellata, Naididae). ORG DIVERS EVOL. 2017; 17(2): 477-495.

15. Statistical Analysis System (SAS). Statistical Analysis System, User's Guide.Statistical. Version 9. $1^{\text {th }}$ ed. SAS. Inst. Inc. Cary. N.C. USA. 2012.

16. Jaweir HJ, Al-Janabi EOS. Biodiversity and abundance of aquatic oligochaetes-family Naididae in the middle sector of Euphrates River, al Al-Mussayab City /Iraq. IJEW. 2012; 1(1): 122-130.

17. Rhadi MM, Nashaat MR, Dauod HA. Assessment of the waste water effect on the oresences and the density of Tigris River benthic fauna by using biodiversity index in Al-Kut City. JOK . 2017; 16(1): 127-136.

18. Jaweir, HJ. A new record of three tubificid species (Annelida: Oligochaeta) from Al-Hawiezah marsh, Iraq. MJMS. 2011; 26(2):114-121.

19. Jaweir, HJ, Al-Sarai MH. The aquatic annelid community in Lake Al-Delmage( Iraq). Biologia. 2016; 71(1): 1-6. 
التشخيص المظهري والجزيئي لانواع الجنس Limnodrilus Claparede,1862 ( سرجيات ــ العائلة نايديدي) في نهز دجلة / بغداد ــ العراق

هيفاء جواد جوير

\author{
ايناس عودة زائر \\ قسم علوم الحياة، كلية العلوم للبنات، جامعة بغداد، بغداد، العراق
}

جمعت عينات ديدان الوحل من رواسب نهر دجلة للفترة من تثرين ثاني 2018 ولغاية تموز 2019 في منطقة الصر افية / بغدادـ

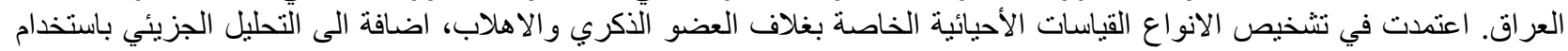

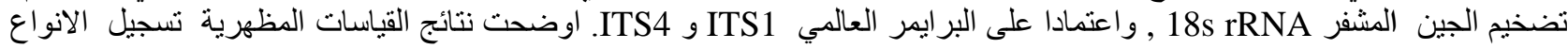
و L. cervix Brinkhurst, 1963 و L. claparedeianus Ratzel, 1868 L Limnodrilus hoffmeisteri Claparède 1862

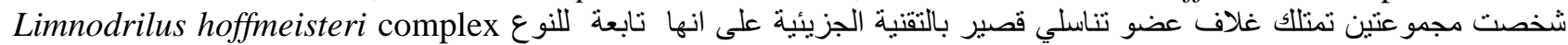

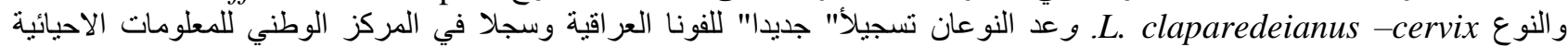
NCBI

Limnodrilus claparedeianus -cervix, والنوع L. claparedeianus, و النوعات المفتاحية: النوع Limnodrilus cervi

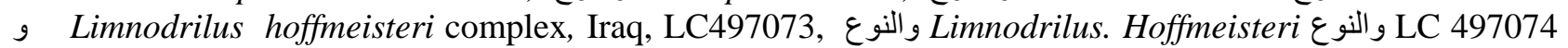
المركز الوطني للمعلومات الاحيائية. 